\title{
The Third World Debt Crisis: Towards New International Standards for Contraction of Public Debt
}

\author{
By Anthony Carty
}

\section{Introduction}

The debt crisis of the developing countries gives rise to great concern about the stability not only of the international financial order but also of the international legal order. The debts, when contracted with private Western or other international banks have been in the form of legally binding agreements to which a regime of law is supposed to apply. This is usually New York or English law. However this system of law is purely private and national. The local courts have the responsibility to have regard to considerations of public policy exclusive to their own national interest.

Such a limited national legal horizon is inadequate where the executive authorities of that country, in particular the United States, are engaged in policies which have effects especially difficult for the developing countries, while being substantially advantageous, even if only indirectly, for the Western banks and public lending institutions. In practice it is recognised that the international' private law regimes are not even intended to regulate the types of difficulites which have arisen with respect to lending to developing countries since the late 1970s. Consequently banks have rarely resorted to national courts.

How is the international lawyer to respond to the numerous calls for the renegotiation and cancellation of third world debts? How is he to characterise an actual practice which appears frequently to involve abandonment of the specific terms of agreements once solemnly concluded? What is he to make of the declarations, increasingly in general international fora, that there is a need for a fundamental reform of international financial law?

In my view the international practice with respect to private bank loan agreements reflects the fact that they lack the guarantee of a public international legal order. Adjustments of agreements are purely ad hoc and do not reflect any clear statement of financial or legal principle. This is not specifically the responsibility of either of the parties, essentially private, to these agreements. They cannot be expected at the same time as they contract loan agreements, to conceive of a public international monetary order adequate to direct how they should respond to a rapidly changing international financial environment.

Yet how might a public international monetary legal order be constructed? The main focus of debate at the moment within the World Bank and IMF fora is apparently economic. In my view they involve a too narrow definition of social and political problems in 
pseudo-economic terms. In particular the demand of developing countries and progressiver Western circles for a substantial expansion of credit to the third world represent highly questionable reconomistic assumptions about the possibility of simply spending one's way out of the crisis. At the same time calls for deflationary rigour on the part of the developing countries are based on economic arguments that leading Western countries are either not willing or not even able to apply to themselves.

The fundamental disagreements about world economic policy show the limited extent to which there exists the measure of political integration necessary to support a world public legal monetary order adequate to guarantee a framework for the conclusion of private international loan agreements. At this stage it is premature to conceive of a reform of the international monetary system in a form which could satisfy rhetorical demands for a just monetary order which might be shaped democratically by all those affected by it.

International society remains too horizontal in its structure. However this very horizontality allows one to appeal to a measure of fairness which ought to be implicit in the concept of the equality of states. The question should be asked whether any state should be expected to accept restrictions upon its contraction of public debt which are flagrantly disregarded by other states. It might be argued even more categorically that international private banks should not complain about disregard for their loans where they contracted them without heeding the necessity for a basis regulatory and democratic framework in the state to which they chose to lend. In other words a serious contribution which international lawyers could make at the present time to the alleviation of the dangers of international debt crises is to encourage the development of standards for the contraction of public debt, from whatever source, which would would be common to both developed and developing countries.

\section{The Nature of the Third World Debt Crisis}

In economic terms the third world debt situation can most likely be characterised as unusual and irrational. There was an overhang of capital in the 70s, coming mainly from the withdrawal of oil dollars from the international economic system. It was reabsorbed in developing countries without regard to whether it could eventually reproduce itself. As the World Bank remarks in its recent reports on Development and the Debt Service ${ }^{1}$ the unusual features of this 70 s lending, in terms of typical international loans, were the short five to eigth year maturity periods and the variable interest rates which applied to more than $55 \%$ of loans.

It is known from the nature of the eurodollar market itself that the limits for the repayment of principal are usually at best medium term. This is a reflection of the sources of dollars for the market, themselves shourt term deposits. More importantly it is accepted

1 March 1986, Development and the Debt Service introduction to World Debt Tables 1985-86, ILM 1986, 454. 
that interest rates were set to float 1 to $2 \%$ above the libor rate. Such an interest rate clause itself is standard in refering to the libor rate a number of days before the commencement of the new interest period. ${ }^{2}$

It is perfectly clear that individual credit relationship were affected by the deficit financing policies of the main world economic power. The libor rate is no more than a reflection of the US prime rate. The money flowing to and from New York and London is acutely sensitive to any possible disparity of interest rates. So when the US attempted to maintain the value of its currency by greatly increasing the interest it was willing to pay on money deposited in the United States, this had to have an immediate impact upon the interest paid by the developing countries on their commercial loans.

It is too simplistic to say that the US endeavoured to bring anything approaching an unjust enrichment to the banks of its own country. The United States was under pressure in the late 1970s to restore the stability of its currency for the sake of world trade. At the same time the deficit spending of that country is seen as an essential part of the role it plays in spending the world out of recession. The United States can legitimately complain that it is bearing an unjust share of this burden and that the developing countries would suffer less if all developed countries proved equally willing to run the supposed risk of renewed inflation which is supposed to be implicit in the loosening of control over the money supply. Nonethless the triangular relationship implied by the monetary policy of the United States, i. e. loans concluded by private banks, whether American or European, in New York or London or else where, ${ }^{3}$ brings into question the issue whether the loans are really simply the subject of a single national legal system, whatever the loan may itself stipulate.

This is a pattern of debt contraction which is unlikely to be repeated. It is well understood that many banks touted for borrowers and that developing countries diverted a large part of the money to meet current imports and even more unsound demands. It is realised that an essential part of the debt crisis is simply the freezing of future credit. The developing countries borrowed on the basis that they would be able to continue to do so. For one thing the length of the loans was so short that reborrowing simply represented an extension of amortization periods. Yet even more simply they expected to be able to reborrow in order to repay existing loans. While this might not make sound banking sense, neither did the original loans. The drying up of credits when the banks realised how unsound their original loans had been is the single most vital element in the debt crisis identified by the World Bank in its latest report.

Although there are about $900+B \$$ involved, it is tempting for both banks and developing

2 For instance, ed. J.-B. Blaise, P. Kahn, Les Euro-Credits, Librairies Techniques, Paris 1981 1981, Annex 1, p. 690; also P. Sarcevic, Real Interest Rates and the Debt Problem, in Revue des droits des Affaires Internationales, no. 7,1985 , p. 859 at p. 866.

3 The major point stessed in Feb. 1986 at a meeting organised under the auspices of the new international economic order committee of the International Law association in a paper by P. Sarcevic, Two Approaches to the Debt Problem, to be published in 'Foreign by D. C. Dicke, Fribourg University Press in summer 1986, see also article of Sarcevic cited in note 2. 
countries to treat this period of lending as an abberation. For instance Nurrick points out that except in the case of Iran, bankers do not employ default clauses as a reason for prematuring a loan ... The facility is inserted in agreements but not in the expectation that it will be used. In practice they are regarded primarily as a bargaining tool, if and when the borrower runs into difficulty. Nurrick still does not see such clauses, which can go so far as to envisage the mere possibility of default, as at all necessary to bring the borrower to the table with the lender. ${ }^{4}$

In fact the underlying rationale with the banks is purely economic and is set out, once again, by the World Bank. To reduce outstanding loans put the security of remaining claims into danger. The rescheduling has had to be on the basis that one might negotiate postponment of maturity payments. At the same time it was recognised that there was a basic need for the banks to decrease their exposure to developing countries. They have raised more home funds, sold off sovereign risk assets on secondary markets and written down some loans on their books. New loans conform to a more traditional style of lending with the average maturity extended beyond the 15 years achieved in $1984 .^{5}$

Nonetheless at the present time the poorest part of the world is responsible for transfering capital to the richest. This is economically inefficent. The resources which remain to be developed in the Third World to not have the capital to activate them and hence makes themselves more able to continue to pay their debts. More immediately, the developing countries do not have the means to continue to pay, at previous levels, for the imports of developed countries. So the money necessary for expansion and circulation of resources cannot find its way to where it is needed. In other words it is widely appreciated that the institutional and financial abberations of 1970 s lending cannot really be expected to fit into the international economy of the 1980 s.

\section{Loan Contracts in Private International Law}

It is generally known that the law applicable to loan agreements is usually that of the UK or New York, with a much smaller number submitted to French or German law. What is much more controversial is the extent to which this guarantees the legal security of the loan. Nurrick points out that the primary intentions of this course are the usual ones for international contracts with developing countries, dissatisfaction with the technical quality of the local law and fear of the consequences of a change in local legislative policy amounting to a unilateral change of the contract. ${ }^{6}$ However it has been argued earlier in this paper that such a reliance on a single national legal system does not take

4 L. Nurick, Issues in Negotiating International Loan Agreements with Transnational Banks, United Nations Centre on Transnational Corporations, UN Doc. no ST/CTC/48 New York 1983 section VI: Event of Default Clauses, paragraphs $77-78,83$.

5 See above note 1.

6 See Nurick, opt. cit., section X, Applicable Law and Jurisdiction, paragraph 96. 
account of the triangular 'reality' of international financial business. I believe this is the context in which to consider the possible implications of an absence of specifically public law institutions, whether national or international, relating to international loans.

Is there an international legal monetary order to encompass the international monetary contracts? A legal order to regulate the context of a contract supposes above all that its terms are understood not simply in private law contractual language but in the light of the qualifications of conflicting external interests which are an integral part of any system of public law. Technically in terms of the private international law principle of the autonomy of the parties it is possible for them to choose New York law to apply to the contract. Yet it is questionable whether such a legal system can offer more than an overtly limited reaction to an issue such as the radical revaluation of the dollar. That is to say New York law would hold the parties to the exact terms of the contract, i. e. that the percentage of interest above the libor rate stated must be paid. The courts of a particular vitally interested country cannot go any further.

This appeārs to be clear from the recent New York case law on Costa Rican and Mexican loans In the Allied Bank Case ${ }^{7}$ the US court accepted the applicability of the act of state doctrine, that it would not question the sovereign right of another state to respond to a serious financial crisis as it saw fit. It would simply not allow such a policy, e.g. the suspension of payments on a foreign debt in foreign with private international law rules on the law applicable to contracts the contract was sufficiently connected with the US. The Costa Rican banks had agreed to pay US dollars in New York. The principle attaching jurisdiction was very narrowly drawn. To escape US law the contract would have had to come to complete fruition within Costa Rican jurisdiction. It is a matter of US public policy, given that the US is an international banking centre, that ordinary principles of contract law be observed.

However one has to note that the court in the Allied Banks case clearly recognises and shows or illustrates a deep conflict of public policy amoung different jurisdictions. Clearly the court itself is applying only US private international law. At the same time it makes express reference to what is accepted practice in international financial circles at a point in time where a complete crisis, if it may be on the way, has not yet been reached. It supposes that international loan agreements are made in an environment of international lending practice which the court is entitled to take into account. Of course it relies entirely upon the US executive power for an exact interpretation of this environment, and a lawyer as experienced as Carreau considers the executive interpretation given in this case to be manifestly inaccurate:

"... The Justice Department brief gave the following explanation of our government's support for the debt resolution procedure that operates through the auspices of the IMF. Guided by the IMF, this long established approach encourages the cooperative adjustment of international debt problems. The entire strategy is grounded in the understanding that, while parties may agree to renegotiate conditions

7 United States: Court of Appeals for the second circuit, No. 83-7714, March 18, 1985, in 1985 ILM 762. 
of payment, the underlying obligation to pay nevertheless remain valid and enforceable. Costa Rica's attempted unilateral restructuring of private obligations, the United States contends, was inconsistent with this system of international cooperation and negotiation and thus inconsistent with United States policy ...." ${ }^{8}$

In this particular case the vast majority of the banks had in fact already concluded mutually satisfactory renegotiations with Costa Rica and the court action concerned an initiative from a 'maverick ' bank' engaged in a test case. Rather more striking are the remarks of Carreau, the leading French monetary law specialist, which make acutely clear the relative national interest involved in the judgement reached. In his view the court twisted both law and fact. In US law domicile of the debtor is usually the location of the debt. Furthermore, to treat the Costa Rican moratorium as a repudiation of the debt is pure misrepresentation. The lower court was more correct to treat it as a simple delay of payment and the IMF had recognised this procedure as valid under art. 8 of its Articles of Agreement. ${ }^{9}$

While US courts may be expected to continue to take account of what the US percieves to be its national interest, it appears no overstatement to say that the contract has to depend upon notions of what is generally accepted practice in international financial circles. This environment may well be in a state of crisis. Such a question is not posed in this context in terms of a model of economic justice. Rather the intention is to ask in purely scientific legal terms in what circumstances and how far the actors directly involved expect such a principle as pacta sunt servanda to be observed to the exclusion of other possible considerations.

It is recognised that developed country lawyers do not always resort to the rhetoric of pacta sunt servanda in attempting to upbraid the developing countries to keep their loan agreements. At the theoretical level, for instance, the Director of the Crédit Commercial de France in 1981 stressed in his discussion of the relationship between default on loans and state juridical orders, that

". . Les conventions d'euro-crédit constituent la charte des parties et en fait le fondement unique de leurs droits respectifs (banques participantes, emprunteurs, banque agent). Il est donc fondamental qu'elles soient aussi complètes que possible.

L'esprit de solidarité au sein de la communauté bancaire internationale est l'un de ses biens les plus précieux. Il est la pierre angulaire de toute solution lorsque des difficultés surgissent . . ."10

In my view the significance of these remarks lies primarily in their apparent recognition that the bankers are very much son their own' and so need to provide for as many eventualities as possible themselves.

In the same vein Jacquemont insists that the choice of a particular national law is

8 Ibid, at p. 764.

9 D. Carreau, note on the Allied Bank Case in Journal de Droit International, 1986, pp. 124-5.

10 P. J. Monnory, Defaillance de L'Emprunteur et Ordres Etatiques, in Les EuroCrédits, opt cit. p. 568 at p. 592. 
merely a first stage in the determination of the appropriate law, designed to exclude the arbitrary application of a completely irrelevant or unsuitable legal regime. The detailed professional practices which operate in the euro-dollar market frequently do not find any reflection in the legal system of any particular country. Many contracts explicitly accord the applicable law a purely subordinate role, indeed an obvious rendering of the principle of the autonomy of the parties. Yet in this case it is a reflection of the intensely technical and delicate nature of the issues and the need that they be regulated as far as possible by those directly engaged through negotiation. Clearly imperative rules of national law cannot be ignored. However a contract which refers to professional usages intends national law to play a subordinate role. In this context he asks the rhetorical question whether such usages should possibly include the notion of res sic stantibus. ${ }^{11}$ It is a small step further, in the light of the Allied Bank Case, to say that the professional usages will be considered by a court whether or not they are explicitly mentioned in the contract as a source of applicable law. Yet the usages themselves reflect a deficiency in the national legal systems with respect to effectives responses to their legal difficulties. At the same time the fact remains that no court can go against its own generally established concept of rordre publicr.

\section{Analogies between the Private International Law of Loan Agreements and the Public International Law of Treaties: the Parallel Absence of a Public Order}

International loan agreements suffer and enjoy advantages and weaknesses similar to those which affect international treaties in the particular sense that there is no impartial international institutional framework to resolve the difficulties of their exceptionally unstable environment. They must clearly be observed in good faith. Yet it is recognised that changes in circumstances may require the parties to renegotiate. The legal formula of the Vienna Convention (art. 62) is that where the basis on which the parties contracted has changed in an unforeseeable way and radically altered the obligations of the parties they must renegotiate. The fundamental structural weakness of public international law is that none of these terms have any definite meaning and there is no rigorous institutional mechanism to give authoritative interpretations. ${ }^{12}$ It is a question of emphasis how one interprets this situation. Hardly anyone would dispute that it is most desirable that as far as possible the parties should endeavour to reach new agreements through negotiations. There is ample state practice where so much has been attempted. Equally one can point to diplomatic incidents where strong protests have followed apparently premature unilateral breakoff of negotiations and of the agreement. However it appears to me that

11 Jacquemont, Emission des Emprunts Eurobligatoires et la souveraineté des Etats, Bruxelles, 1975, pp. 179-182.

12 See the recent study by A. Vamvoukos, Termination of Treaties in International Law, Oxford University Press 1985; also a very similar approach taken in A. Toth 'The Doctrine of rebus sic stantibus in international law' Ph. D. thesis Exeter 1970; and A. Carty, 'The Decay of International law' 1986 Manchester, chapter 5. 
practice with respect to treaties and even as well with respect to loan agreements provides no clear indication that, in the absence of agreement being reached on renegotiation, the debtor may not take the view that circumstances objectively merit a unilateral modification of the debt. There are no precise rules defining what is foreseeable, basic or having the effect of radically transforming obligation.

Vamvoukos discusses the two well known international instances concerning loan agreements which do not point in any particular direction. In the 1930s the French did not consider they had a legal right simply to repudiate their war debts towards the US. However they took the firm view that the cancellation of German war debts called for new arrangements, that France was legally justified in demanding wholescale revision of its debts. It suspended payments. The United States never accepted the principle that the debts were no longer repayable. However it acknowledged the existence of changed circumstances and accepted the necessity for rearrangements ${ }^{13}$ In the Russian Indemnity Case the Permanent Court of Arbitration accepted the applicability of the slightly different principle of force majeure, but considered that it did not apply to the facts. Turkey alleged that it had difficulties in making payments to Russia. Yet the Tribunal noted that Turkey was at the same time able to obtain loans at favourable rates, redeem other loans and pay off a large part of its foreign debt. It was complaining about a comparatively small sum. ${ }^{14}$

All of this argument goes to show that the simple language of pacta sunt servanda and rebus sic stantibus has never been evolved sufficiently to consider the complicated issues arising out of the present debt crisis. The issues are clearly not the precise responsibility of either of the two series of parties. This is the foundation of the generally recognised duty to renegotiate something which neither side seems to be disputing. So it is not surprising to find that international bankers are acutely aware of the precarious financial position of both creditors and debtors.

The specific details of renegotiations are kept confidential. It appears, according to Prof. Hahn, that the parties are unwilling to devise at present any general principles for renegotiation, that they prefer to treat each case concretely. Repeated statements by developing countries that they are not responsible for a virtual inability to pay, that circumstances have changed dramatically etc, such strong language is almost never accompanied by any specific actions to undermine their agreements.

In my view instead of making very general rhetorical statements about the doctrines of pacta sunt servanda and rebus sic stantibus, both essentially private law contractual notions when used in the present context, one should recognise that an international public monetary order is lacking. It is clearly not felt by any of the parties most directly engaged that their fragile contractual relations should collapse. However it is not enough simply to say that a complete legal system covers their situation because they are under a

13 Vamvoukos, opt cit. pp. 95-97.

14 Ibid. p. 175; see Russian Indemnity Case, Permanent Court of Arbitration 1912, Hague Court Reports pp. 297-328. 
legal duty do negotiate with one another in good faith. The international monetary order has to be matter of distinct regulation by states whose power is generally recognised as economically significant.

\section{Macroeconomic Management of the Debt Crisis}

The Spring 1986 Congressional (House of Representatives) Report, ${ }^{15}$ the contemporaneous World Bank Report ${ }^{16}$ and the Baker Plan ${ }^{17}$ all suppose an essentially extra-juridical, macroeconomic approach to the debt problem. The first of these calls for a simple recognition that there is a long term unsustainability in recessionary austerity plans, usually seen as essential to the earning of foreign exchange to pay off debts, and the inevitability of some outright debt relief. More fundamentally the Congressional Report accepts the roll-over character of the short term debts and the inevitability of granting further loans. It appears difficult to persuade the private banks to take the lead. However the World bank itself is to be encouraged to do so, in undertaking co-financing with private banks, coordinating stabilisation plans with the IMF and making its own loans to stimulate economic expansion. Indeed the assumption is that without such measures the developing countries will probably default, given the economic forces at present arraigned against them.

The World Bank in turn stresses the intractable nature of the macroeconomic problems facing the developing countries and having a devastating effect on their ability to repay their loans. For instance there has been some progress on the issue of the effect of national interest rates on the interest paid on loans. The developed countries recognise here the direct and clear impact of their interest rates and trade protection policies on the developing countries debt problem. The policy of reducing the value of the dollar and lessening US interest rates has had the effect of bringing the six month libor rate down from $11.2 \%$ in 1984 to $8.6 \%$ in early 1986. This is progress even if not enough. However when the substantial beneficial effect is adjusted to take account of deterioration in developing countries terms of trade, expecially because of falling comodity prices, the outcome means a real interest rate equal to $10 \%$. Commodity prices are down $15 \%$. The recession in the Western economy is bringing the rate of growth down from $5 \%$ to $3 \%$. So the conclusion of the World Bank analysis is that nothing short of more general expansion, which the US now considers should be undertaken primarily by Japan and West Germany, can alleviate the condition of the developing country debt. It is in this context that the World Bank further stresses Western acceptance of the need for an

15 US Congress House of Representations Committee's Subcommittee on International Development Institutions, March 1986, in 1986 ILM 439 et seq.

16 See note 1., The World Bank 'Development and the Debt Service'.

17 Treasury News, Oct. 8, 1985 Statement of Secretary Baker before the IMF-World Bank Joint Annual Meeting. 
expansion of transfer of capital on a medium term basis to stimulate economic growth through structural change rather than simply stabilisation, although strict surveillance from the IMF should remain.

What is at stake here is precisely the global economic planning and official acceptance of economic responsibility which in my view make up the substance of the insistance that an international contract must be effectively subjected to a system of law. However it appears that the minimum conditions for such a legal order are not present for the moment. For instance the proposals just discussed concerning money and efficiency raise basic questions of economic theory. The predominant Western theory at the moment is that of monetarism.

This appears to assume that the state is not competent to take grand economic decisions as to how capital can be effectively invested to develop resources. There is no clearly proven link between its capacity to release technological or physical potential and real market need and demand. Instead the financial system supported by the state should limit itself to ensuring that inflation is reduced by a tight control of the monetary supply. Then interest rates may come down so that the private investor can hope to obtain money at a price which is reasonable in terms of his capacity to obtain profit following upon investment. ${ }^{18}$ Hence it is not surprising that West Germany, Japan and other developed countries are resisting the call for economic expansion on the ground that it will only prove to be inflationary.

While it is obvious that the individual is not compelled to borrow for the purposes of productive investment when money becomes cheap, it is clear, in the monetarist view, that the variables which eventually lead to the vital stage of satisfaction of market demand and consumption are too many for the state to hope to intervene successfully. It is in such a context that the interest rates have gone up and the developing countries have found themselves having to repay more than $40 \mathrm{~B} \$$ extra. ${ }^{19}$ Given that their part in the international economic system is not perceived to be vital it is hard to imagine that any fundamental change could be made on their account.

So it is not surprising that discussion within the IMF framework about the possible parameters of global macroeconomic policy with respect to the debt crisis have not been very conclusive. There have been special reports by both the developed (Group of 10) and the developing (Group of 24) countries in the autumn of 1985. The two salient features of the latter Report are in my view that they call for a level of interstate coordination of macroeconomic policy which is inconceivable, and secondly, they admit, quite frankly, that they have no reason to believe that such cooperation would in any case have predictably beneficial consequences for them. Firstly in the view of the Group of 20 Art. IV surveillance should encompass multilateral negotiations about a mutually consistent set of objectives and policies amoung the major industrialised countries. This implies com-

18 For a concise summary of opposing contemporary views see K. Cole J. Cameron and C. Edwards, 'Why Economists Disagree: The Political Economy of Economics Longmann, Essex, 1983.

19 See figures cited by Sarcevic in Two Approaches to the Debt Problem, note 3 above. 
plementary use of monetary, fiscal and other policy instruments consistent with exchange rate stability and growth without inflation. ${ }^{20}$ The debt crisis itself is seen primarily in terms of inadequate liquidity to match the realı need of developing countries for finance. $^{21}$

Yet whether developing countries can match economic growth with a capacity to repay their existing debts depends upon a set of economic variables with respect to which considerable uncertainty exists. Industrial growth in the developed countries, stable exchange rates, restraint from protectionism, adequate measures of adjustment in developing countries, and their development of interest rates and the value of the dollar, are all relevant factors. It is easy to imagine that just one of these would evolve unfavourably and have a cumulative adverse effect on the others. The outcome would be to pose

'. . . the risk that for at least some debtors the situation would become unsustainable. Without clear signs of economic progress the governments of debtor countries would be faced with political and social pressures making it difficult for them to reconcile the objectives of restoring growth in their countries with the prospective payments of debt service ... . (22 $^{22}$

This is hardly a radical threat. Yet it is a highly controversial and purely technocraticeconomistic analysis by the developing countries of the nature of their situation.

Criticism of a possibly salutory role for the IMF as an international monetary policeman runs up against much the same queries about the soundness or viability of world macroeconomic management. Something has been made of the increased role of the IMF in the most recent renegotiations of the loan agreements. The IMF has only been willing to play its police role in return for a willingness on the part of the international banks to roll over debt. Here is where the IMF has stepped in at least to some degree. It is definitely fullfilling the role of an international public monetary order. ${ }^{23}$ The question remains whether it is competent to do so. In purely legal terme this issue is vital because there is no implication that the IMF would be legally responsible to the banks in the event that the developing countries failed to repay any of their present and to be contracted debts. The banks are relying upon the policing function implicit in the IMF insisting upon stabilization policies simply because in their view their prospects for repayment in the absence of such surveillance are even sleighter.

Yet controversy in economic theory comes back to hit the IMF's stabilisation policies in turn. Its record of success in the application of these policies to Latin American states in the last twenty years is proven to be completely indeterminate. ${ }^{24}$ The reasons for this may

20 IMF Survey, Sept. 1985, Suppl. on Group of 24 Report paragraph 9 et seq.

21 Ibid, paragraphs $38-42$.

22 Ibid, paragraph 146.

23 See for instance IMF, Occasional Paper, no. 25, Recent Multilateral Debt Restructuring with Official Bank Creditors, 1983, and Occasional Paper no. 40 Recent Developments in External Debt Restructuring, 1985.

24 See for instance M. Sutton, Structuralism: The Latin American Record and the New Critique, in The IMF and Stabilisation, Developing Country Experiences, edited T. Killick (Overseas Development Institute) London, 1984, at pp. 19-67. 
lead theorists in many directions. Yet the simplest agreed ground for scepticism is the reliance of the IMF on so-called macroeconomic variables and assumptions about the efficiency of the private sector. Recently the IMF has stressed its desire to combine demand management with supply stimulation (pricing policies, tax incentives etc) to boost production and employment. ${ }^{25}$ However its ideological confidence in the private sector is taken to be misplaced, because in developing countries there is frequently a lack of market transparency, social constraints, such as a lack of the profit motive conspicuous consumption, and other anomolous effects. For instance allowing production prices to rise may only start a prices spiral, without necessarily improving the supply of the relevant commodities, whose shortages are of ten caused by transportation and distribution problems. ${ }^{26}$ More fundamentally it is recognised that macroeconomic theory itself is in a confusing state. Market forces and exchange rates do not clearly correspond. There are doubts about the right definition of domestic credit in economies with diverse financial institutions, not to mention the basic difficulty of estimating the gestation period for fixed investment credits on production and the balance of payments. ${ }^{27}$

As it is increasingly doubted that economies can be managed by the manipulation of the level of public credit, the presence or absence of import and exchange controls, the IMF is thrown back upon a so-called pragmatism which amounts to no more that an ad hoc consensus with state officials who consider they need the loan facilities whatever the conditions. Mistakes or uncertainties about economic theories may not be decisive where they are merely the subject of national economic policies, but they cannot be allowed to plague an international monetary policeman. It can hardly continue to function as such. The IMF is a supposedly technocratic economic think-tank and the issues it has to face are clearly not purely economic.

This doubt about macroeconomic theory makes one less willing to accept the rigours of deflationary financial stringency as applied to developing countries. It appears that the Group of 10 Communique of 8.4. 1986 purports to relieve the developed countries of any duty of care towards the developing countries with respect to the administration of their own developed country public deficit ${ }^{28}$ and this brings the prospect of unilateral radjustment' to economic 'necessities' all the nearer. The developed countries reaffirm the analysis of the Group of 10 Report (of July 1985 IMF Survey) that no major changes are required in the present institutional setting for exercising surveillance over national policies, including those concerning public deficit financing. They go no further than to say that it might be useful, in the context of exchange rate policy, to consider the employment of indicators for the assessment of convergence and policy consistency both domestically and internationally. The IMF might look at the matter further. This state- 
ment is a firm enough refusal of the principle of co-responsibility between developed and developing countries with respect to the world financial crisis. It represents an unwillingness to engage in good faith in a renegotiation with those directly affected by the changing international environment, and, as such, is an invitation to the unilateral radjustment' to which I have already referred in the final part of the first section of this paper.

One can draw such a radical conclusion from various speeches of de Larosiere, Managing Director of the IMF, outlining the concept of co-responsibility, and in particular that of $15.11 .85 .{ }^{29}$ It is clearly not disputed to any general degree that a cooperative solution is essential to avoid a breakdown of the financial system. Hence there is a relative absence of rhetorical florishes by developing countries about the breakup of the existing system. He offers fairly careful adherence to the spirit of the principle of public international law that an argument for radically changed circumstances with respect to a contractual obligation is first and foremost an insistence upon a duty to renegotiate in good faith. After recording progress made between 1982 and 1985 de Larosiere considers the usual causes of the unstable economic environment, placing special emphasis on the inadequacies of the fiscal policies of the developed countries:

... The supply of global savings is just too limited to meet large government demands on it without pushing up world interest rates. By virtue of its size alone, the United States must take the lead by significantly reducing its structural budgetary imbalance. Such action would contribute to a needed lowering of interest rates worldwide, to an orderly reduction in the exchange value of the dollar, and to the necessary correction in the US current account deficit...

$\therefore$ Indeed, it is difficult to overestimate the benefits in present circumstances of a significant and credible reduction in prospective U.S. fiscal deficits ...

The key first step in developing legal principles for the construction of a new international financial order in the given context of a third world debt has to be agreement upon universally applicable standards for the contraction of public debt, i.e. both for the developing and the developed countries. Even if one were to accept the most hostile Western criticism of the developing countries, which is that the contraction of debt was an aspect of unsound public deficit financing, the outcome would only be to identify the developing countries with the developed themselves. So it should appear possible to see a connection between the not very successful attempts to control public expenditure in some Western societies and the inability of the developing countries to control the expansion of their debt. A common approach can and should be found. 


\section{The Sovereign Equality of States and Common Standards for Public Debt Contraction}

There is at the global level an inability to develop effective and democratic means of control of public expenditure which apply to all countries equally. It makes little economic sense to transfer net capital resources from the South to the North, the well-known effect of the present debt situation. At the same time there is no clear unjust enrichment on the part of the Western banks. For one thing they lend money very much at the rate at which they obtain it themselves, i.e. if taken individually and not collectively. They have no control over the impact of public deficit expenditure in developed countries. The suffering of the developing countries reflects the absence of any international legal technique to mitigate the burden which generally uncoordinated public-deficit expenditure adds to the specifically third world debt crisis.

The rhetoric of economic self-determination surrounds the language of the new international economic order. This does give some indication of safeguards which might accompany the contraction of further public debt by developing countries. For instance, it is recognised that the conditionality which is accompanying the renewal of commercial loans affects directly the interests of the whole populations of the developing countries. Therefore it is sensible to open up a process of economic decision-making which is seen at present to escape parliamentary control and the pressure of directly affected interest groups. Without social consensus one might expect that policies which have major distributive consequences will not be maintained..$^{30}$ Indeed it is only a short step further to argue that they need not be maintained. The principles of self-determination and development should find their place in the actual institutional framework required for the conclusion of international loan.

The parallel has been conceded in principle already in the context of investment protection and promotion treaties. The duty to honour Western investments in a developing country is frequently made conditional upon a constitutional approval of the investment by the President or Parliament of the developing country. This guarantee is not as a rule absolute, but the clear responsibility of the developing country is to ensure that the investment is accepted within the context of a considered national economic development plan. ${ }^{31}$

Some immediate legal implications may appear to follow from this course. Firstly legal opinion could develop the consensus that both banks and the IMF can be expected, as a matter of proper commercial practice, not to conclude loan agreements without the satisfaction of these basic legal procedures by the developing countries. If they choose to go ahead they have to accept the consequence that the security of their transactions should rest upon the continuity of the political actors with whom they have had to deal.

30 This argument is developed further by K. M. Meessen, in State Sovereignty and the Conditioning of Loans to be published in 'Foreign Debts in the Present and a New International Economic Order', opt. cit.

31 A recent comprehensive survey is provided by J. Plaviec, 'Protection et Promotion des Investissements ' Etude de Droit International Economique, P.U.F. Paris 1985, esp. pp. 54 et seq. 


\section{Public Debt Contraction and Economic Self-Determination: The Case of Mexico}

A detailed case study of recent Mexican experience can suggest some of the basic institutional measures which banks should be expected to require before they are willing to lend to developing countries. These measures should be seen as a parallel to those which have evolved in the context of investment protection treaties. At the same time, given Mexico's traditional role as one of the most vocal proponents of a new international economic order one may still ask whether Mexico's institutional response to its financial crisis has been truly democratic or in any sense radical in its own domestic terms?

A leading Mexican authority on the debt problem, Rosario Green, has pointed to the details of economic rationality and irrationality which led to the massive expansion of the external debt of Mexico in the late 1970s. The political system did not favour the expansion of public resources through a reform of the taxation system, i.e. an insistence upon a greater contribution of the private conglomerates to the Mexican Treasury. The technocratic elite was not so incompetent as to be ignorant of the consequences of inflating the domestic money supply. There was a recession in the West, with capital available in the form of loans to finance Mexican economic expansion. The competition for a choice developing country was intense. The loans proceeded without any substantial supervision by either the banks or public authorities for either the public or the private sector. The lending was increased in the course of 1981 as the price of oil and other Mexican exports declined. This conduct was bound to lead to crisis. ${ }^{32}$

So much is readily appreciated by the Mexican technocrats. The question is how to change course. A first institutional step is easy, to reform the financial institutions of the country to ensure adequate supervision in future. The 1985 Law regulating the public service of banking and credit tightens up procedures. ${ }^{33}$ These involve quite basic matters such as according exclusive authority to national credit bodies to receive public income and dispense loans. The law insists that lending banks should be separated from interests in industrial or other enterprises, that their commissions and interests should be controlled by the Bank of Mexico, and that the latter in turn should follow the policies of the Treasury. The law is designed to provide the machinery for this purpose.

In turn the new organic law of the Bank of Mexico tries to tighten up its role as a guarantor of credit. It had a duty to maintain in reserve in foreign currency a quarter of the currency in circulation in the country-ineffective because of continuous and rapid devaluation of the national currency and a freezing of foreign assets. Now it simply proposed to limit the internal finance of the bank to a sum fixed by its governors in terms of the national development plan and the projected future public spending set out in the

32 R. Green, 'Mexico: crisis financiera y deuda externa, El imperativo de una solución estructural nacionalista', Commercio Exterior, vol. 33 num. 2, (1983) pp. 99-107.

33 Exposición de Motivos de la Ley Reglamentaria del Servicio Publico de Banca y Credito, the Diario Oficial of Mexico on 14 January 1985; also in Commercio Exterior, vol. 35 no. 4, (1985). 
budget of Congress. Decisions on the granting of credit etc will be taken with senior officials of the Treasury. ${ }^{34}$ For the year 1985 the sum was to be determined by the governors in the light of the macroeconomic objectives of the national government, of which the most important was taken to be a reduction of inflation. ${ }^{35}$

It appears to me that these reforms are elementary if essential measures of rationalisation. Any international banks which concluded loans with a country which did not have such a framework of control would deserve the consequences. The question is whether this can amount to or lead to any democratic participation in the terms and conditions of international finance. A consideration of the published 1985 letter of intent of Mexico to the IMF would suggest not.

It appears clear that the present Mexican governing-technocratic elite do not consider they have any options to escape the exigencies of economic rationality. The Treasury and the Bank of Mexico accept that the best way to ensure the welfare of the population is to improve the performance of the economy. The only way to do this is through reduction of inflation. The only important concession of principle is that increasing the national budget through a reform of the base and administration of direct taxation has proved essential. Yet this is not to say that any concerted effort would be made to chase after the 22 billion dollars which fled the country in 1981-1982. Such a course would infringe the most important economic right of the Mexican property owning classes, to take their wealth out of the country at will.

So the basic focus of most of their proposals is on pure rationalisation of expenditure. So no loans may be made to public companies without the approval of the Treasury. Their debts are to be paid directly by the latter. A consistent attempt is to be made to adjust prices which are at present fixed to some notion of rational cost of production, having regard to what the country can afford at its present level of development. Similar considerations are to apply to the reform of the System of public subsidies. ${ }^{36}$

There is no indication that the Mexican governing PRI and technocratic elite accept any substance to the rhetoric of economic self-determination. There is no question of finding a place for a more extensively democratic discussion of the issues of debt, and in particular an identification of those who benefit or lose from its existence. Instead they form an energetic element of the Group of 24 which has already been considered in the second part of this paper.

34 Exposición de Motivos de la Ley Organica del Banco de Mexico, the Diario Official of Mexico, 12th November 1984, also in Commercio Exterior (supra) p. 408.

35 Determinación del financiamento interno del Banco de Mexico, Objetivos de Politíca Financiera para 1985, in Commercio Exterior (supra) pp. 412-413.

36 Carta de Intención al FMI, Secretaria de Hacienda y Credito Publico, Banco de Mexico, in Commercio Exterior (supra), pp. 414-418. 


\section{Democratic Control of Public Debt as a Problem Common to North and South: A Case- Study of UK Debates}

So there are serious reservations to be had about the rhetoric of the new international economic order in the present context. It is relevant to stress the clear inability of public law theorists in developed countries as well to break into the supposed purely economic rationality of public expenditure control. There is a pressing need for substantial advances in the theory of law and economics in so far as concerns not merely the control on public expenditure, but also the reality of democratic participation in the evolution of so-called macro-economic management.

For instance consider the public discussion of the issue in Britain since 1976. This should be particularly interesting given the stance of Great Britain as a monetarist state committed to public expenditure controls and firm limits to inflation as the main feature of its national and international financial policy. The attempt to control public expenditure has proved even technically very difficult. It was only in 1981 that the Conservative administration eventually hit upon the strict regime of cash planned rather than volume planned expenditure. The system of the Public Expenditure Survey had led to close cabinet debate on costing, but was thought to be itself inflationary, because it was an incremental system leading public spenders to argue for more cash from a starting line, rather than questioning the latter itself. ${ }^{37}$

It is a remarkable fact in a Western democracy that the present system does not give Parliament a complete look in. The 1983 Financial Management Initiative introduces private accounting techniques, but these are to be applied directly by senior civil servants responsible for the execution of particular programmes. This involves delegation of authority regardless of the doctrine of ministerial responsibility. The outcome of one of the most serious Western attempts to control and reduce public expenditure has been to keep it firmly outside parliamentary initiative. The only new measure at the constitutional level is the National Audit Act of 1983. By section 6 the Comptroller and Auditor General may carry out an inquiry into the efficiency and effectiveness of any relevant public body in the use of its resources. However under section 2 it may not question the policy objectives of any such body. ${ }^{38}$

There is increasingly debate in British public law circles as to whether any criterion of participatory democracy is satisfied by this regime. It is difficult to see any contrast to the Mexican experience, and one might wonder whether it is somehow inherent in the nature of the material which one is attempting to master. Prossner argues that democracy supposes, following somewhat the influence of Habermas, the development of an increased capacity for problem solving, for coping with the complexities of social development. The options chosen favour very much instrumental rationality rather than the

37 M. Elliott, 'The Control of Public Expenditure', in (ed.) J. Jowell and D. Oliver, 'The Changing Constitution Oxford, 1985, p. 149 at pp. 157-160.

38 Ibid., pp. 162-165, 167-168. 
development of communicative competence. It is doubtful in Prossner's view whether the two have to conflict in principle. The major danger is that the severe limits upon participation in debate means that very little critical analysis of error takes place in Britain. ${ }^{39}$

Yet the dominant view remains that it is a simplistic assumption about the constitution to suppose that public expenditure must be subject to "outside control": The Queen's government should be carried on. "The constitutional freedom of the executive, especially the Treasury, in financial matters is long standing ..." The controlling scrutiny takes place within the executive. As Elliot puts it "... in the field of public expenditure the executive is itself an instrument both of public accountability and public power . . . ${ }^{40}$

\section{Conclusion}

It might seem pointless to try to avoid disagreements about strategies of macroeconomic management at a national or international level by resorting to debates about common standards of public law for the contraction of public debt. For instance all of the Mexican controls do not really amount to safeguards for the economic self-determination of Mexico. They do satisfy a purely formal conception of Mexican national interest. That is to say they suppose that the Mexican authorities have worked out exactly what their economic and financial policy is and where their foreign debts are expected to fit into that picture. Developed countries have understood their duty to respect the economic sovereignty of developing countries to mean a duty to respect whatever development and other plans the latter have been able to formulate clearly and hold to consistently. Mexico appears to provide this minimal institutional guarantee. However its preoccupation with control of inflation and with the introduction of a larger share of market considerations into its economic planning are required by its relatively subordinate position in the international economic system, particularly in its relation to the U.S. and the IMF. It may be unrealistic to try to introduce some substantive as distinct from formal standard of public debt law such as that finance from public debt should not be diverted to nonproducitive endes, e.g. military or social expenditure, or payments on current account for imports beyond, for instance, a certain percentage. This simply reintroduces all the economic controversies outlined in the second part of the paper. That is to say there is no agreement amoung theorists of political economy about how usefully the public sector can direct investment. At the same time one can see the objection made that whatever money such restrictions on public expenditure in developed countries may save, it does not, in any case, "belong" in developing countries however usefully or productively it might be invested there.

39 T. Prossner, Democratisation, Accountability and Institutional Design: /Reflections on Public Law in (ed.) P. McAuslan and J. F. McEldowney, 'Law Legitimacy and the Constitution', Sweet and Maxwell, London, (1985), p. 170 at pp. 173, 176-181.

40 Elliott, 'The Control of Public Expenditure', pp. 172-173. 
Nonetheless it appears to me that the lawyer can contribute to the development of standards to ensure an increasingly democratic and therefore formally just contraction of the public debt by developing countries. That is why the suggestion is made at this very first stage, and hence the concentration upon the particular UK experience, upon the evolution of common formal standards of democratic approval of contraction of public debt. It should not be considered as fair, and as compatible with the principle of the sovereign equality of states, to impose upon developing countries standards for the further contraction of debt, for instance those which usually accompany IMF conditionality, without ensuring that the latter have been able to go through procedures of democratic approval which approximate to those regarded as essential in developed countries. At the same time it is perfectly well realised that the formal democratic procedures of some of the latter are not fully developed and that this is in part at least attributable to the complex if not intractable technical nature of the financial problems which have somehow to be managed. Hence there is a common ground of concern in which lawyers from both developed and developing countries might try to evolve international standards for the contraction of public debt. 


\title{
The Third World Debt Crisis: Towards New International Standards for Contraction of
} Public Debt

\author{
By Anthony Carty
}

The present law relating to third world debts is primarily a law of private international contracts. This subjects them to national legal systems which are not equipped to consider anthing other than the national interest dimension of the contracts, and, of course their exact terms. So even the banks themselves rarely resort to their chosen jurisdictions.

How is the laywer to react to de facto renegotiation, and, in effect modification of loan agreements? The adjustments made are conditioned by the absence of an effective international monetary legal order. How might such an order be constructed? The debate about the role of the IMF and the World Bank is conducted in purely economic terms, with all the arguments employed heavily contested on all sides.

The degree of disagreement about global economic policy is a reflection of the lack of foundation for global political and legal integration. However one contribution to a public international monetary order would be to appeal to the measure of fairness implicit in the concept of the souvereign equality of states. No state should be expected to accept restrictions upon its constraction of public debt which are not accepted by all states. International and public lawyers should work to encourage the development of standards for the contraction of public debt, from whatever source, which would be common to both developed and developing countries. Private banks should be expected to respect these standards.

\section{Legislative Control Executive Power in Africa: New Insights}

\section{By J. B. Ojwang}

Affirmations of dangers inherent in public are not always attended by concrete examples of practical situations, systematically presented and analysed. This article attempts to illustrate the theoretical proposition that the governmental process is apt to veer towards authoritarianism, in the absence of clear mechanisms of control. The focus is the relationship between the executive and the legislature in the typical African state. The substance of the illustration is drawn from the report of the Miller Commission of Inquiry, which as appointed by President Moi of Kenya in 1983, to investigate inter alia the activities of a former leading Minister, with regard to conduct in the office, to relations with the public, and to various public bodies entrusted with defined obligations. It emerges from the study that, in circumstances of indiscipline, or schism in the ranks of the executive, government malcontents will use a variety of techniques to enfeeble the integrity of 